\title{
COVID-19: What we've learned so far
}

\section{Ged Williams ${ }^{1,2,3}$, Wilson Cañon-Montañez $z^{4}$}

History

Received:

April 13th, 2020

Accepted:

April 24th, 2020

1 Founding Chair. World Federation of Critical Care Nurses, Abu Dhabi, United Arab Emirates.

2 Adjunct Professor. Griffith University, Brisbane, Australia.

3 Emeritus Professor. Universidad de Santander, Bucaramanga, Colombia. Corresponding author. E-mail: ged_williams@hotmail.com https://orcid.org/0000-0002-7481-2445 4 Epidemiologist. Associate Professor, Faculty of Nursing, Universidad de Antioquia, Medellin, Colombia. E-mail: wilson.canon@udea.edu.co https://orcid.org/0000-0003-0729-5342
Coronavirus disease 2019 (COVID-19) has dominated almost every aspect of human life on planet Earth since it was first discovered in Wuhan, Hubei province, China, in December 2019ํㅗㄹ . A quick google search of the expression COVID-19 reveals more than 3.22 billion results.

In order to understand the importance of this type of virus, we need to carry out two extremely important epidemiological issues: the basic reproduction number (Ro) and the effective infection number (R). Ro is used to measure the transmission potential of a virus. This number is an average of how many people to whom an infected patient is able to transmit the pathogen, assuming that people close to the patient are not immune to it. Now let's understand R. A population will rarely be completely susceptible to infection in the real world. Some contacts will be immune due to a previous infection that conferred immunity or as a result of previous immunization, due to the action of vaccines. Therefore, not all contacts will be infected and the average number of secondary cases per infectious case will be less than Ro. In this calculation, we take into account susceptible and non-susceptible people. With this information presented, we can conclude that if the value of $\mathrm{R}$ is $>1$, the number of cases will increase, starting an epidemic. For a virus to stop spreading, $\mathrm{R}$ must be $<1$. To estimate $\mathrm{R}$, we multiply the value of Ro by the susceptible fraction of a population 2 .

The spread of COVID-19 from human to human has an estimated reproduction rate of $\mathrm{Ro}=2.28$, that is, each infected person passes the virus onto 2.28 other people on average, much faster than other corona and influenza viruses ${ }^{2}$. The COVID-19 virus has shown itself to be particularly lethal towards older people. As an example, Italy reported greater than $96 \%$ of all COVID-19 deaths are in people aged 60 and over ${ }^{3}$.

The major concern with a rapidly spreading disease like COVID-19 is that the number of critically ill patients requiring hospitalisation, especially among the old and frail, will rise rapidly and overwhelm the health system quickly as we have seen in countries such as Italy, Spain, France, UK and USA. WHO declared COVID-19 a pandemic in early March 2020 and started requesting governments to put in place pandemic response measures to reduce the spread of the disease and prepare the health system to accept 
large numbers of patients with severe respiratory illness ${ }^{4}$. The most strategically useful public health measure in such circumstances is to "flatten the curve" of the disease, that is, reduce the speed at which the virus is spread from human to human so that the naturally occurring high peak in incidence of the disease that would normally occur and would normally overwhelm the healthcare system and kill many lives, is reduced and spread over a much longer period of time so that the health system is not overwhelmed and can hopefully save as many lives as possible with the resources it has (Figure 1), especially intensive care resources which is where the sickest and most vulnerable COVID-19 patients end up.

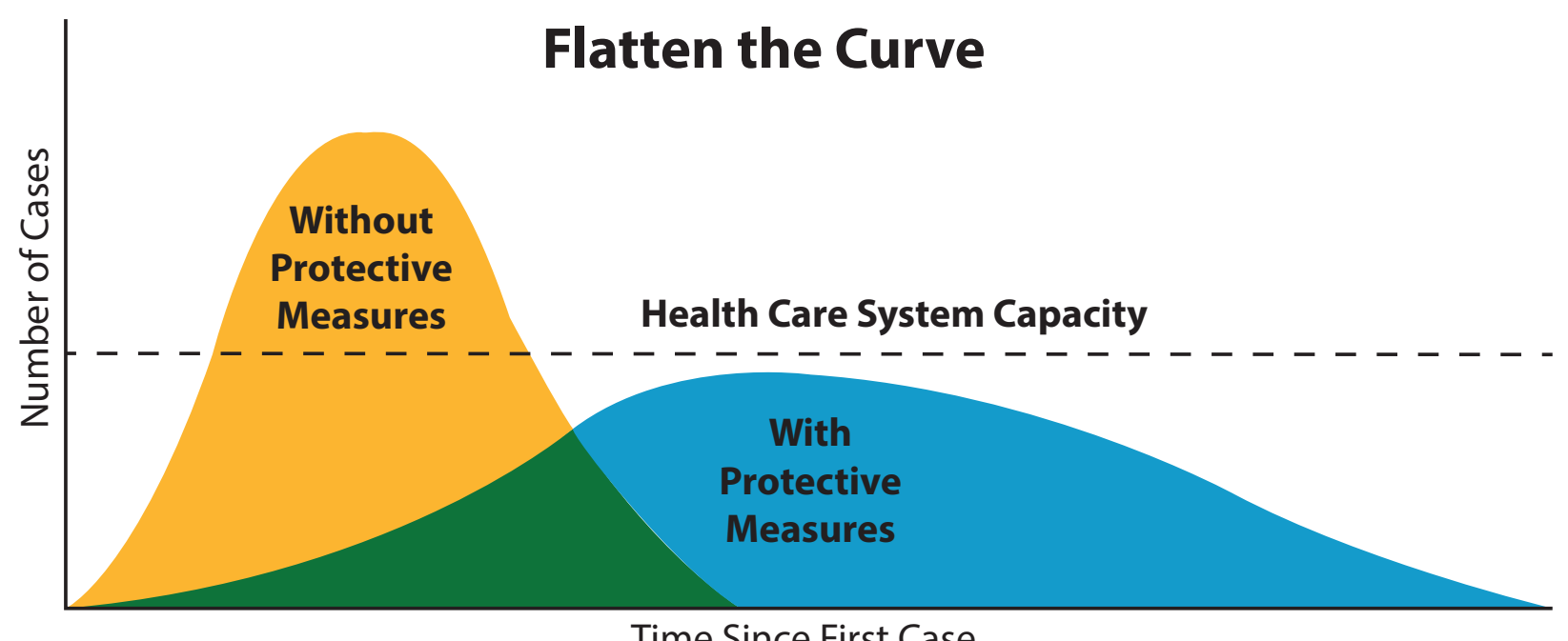

Figure 1. "Flatten the Curve" diagrammatic representation how social distancing protective measures can reduce the rate of transmission of COVID-19

Public health measures during a pandemic of this scale are structured so that messaging to the community is clear and escalating measures are put in place to further flatten the curve $\mathrm{s}^{\underline{*}}$ :

1. Wash hands, cough/sneeze etiquette, stay home if you have influenza-like-illness symptoms, see doctor if symptoms worsen. Social (physical) distancing at least 1.5 metres.

2. Reduce or close large public gatherings such as school/university, concerts and conferences, major sporting events, religious and cultural ceremonies etc.

3. Stop or quarantine people travelling especially those who have been to countries with high COVID-19 prevalence.

4. Stop all unnecessary travel, keep everyone inside except for essential activities such as work, shopping, doctor visit. Mandatory wearing of masks and gloves in community areas.

5. Close all unnecessary services such as restaurants, clothing stores. Stop congregations of 2 or more people outside of the home. Curfew of whole cities after hours. Significant penalties, including imprisonment for violations to the rules.

Many countries of the world are now utilising many of the above measures and more. While some like Australia and New Zealand are now planning to scale back the measures as the growth in numbers of COVID-19 cases per day has dropped to manageable numbers $\frac{6,7}{}$. This has been an unprecedented 
global community campaign with surprising cooperation and support from many in the community, for now.

Predictably, many of our health systems have shown significant gaps in preparedness for this pandemic: i) insufficient numbers of skilled nurses, especially ICU nurses ${ }^{-}$, ii) insufficient equipment, especially ventilators ${ }^{9}$ and iii) insufficient Personal Protective Equipment (PPE) $\stackrel{10}{ }$. These issues have been particularly evident in the countries where COVID-19 hit first and before sufficient information was available to inform these countries, especially China, Italy, Iran, Spain, France, although even with warning some countries have still struggled to prepare for the scale of the challenges such as UK, USA who both have well resourced health care systems relative to most other countries of the world! The message is now very clear, every government needs to review its nursing manpower requirements, and especially how to mobilise large numbers of critical specialists should such a pandemic or similar disaster occur again, in addition, making sure there are sufficient stock piles of equipment and PPE for such events in the future. Nurses and health professionals around the world with leadership are required to advocate for their colleagues to confront this great problem that humanity is living with sufficient PPE, equipment and adequate training ${ }^{11}$.

However, there are two important final COVID-19 impacts to be considered. Firstly, the impact on low and middle income countries (LMIC). Many LMICs have not had large numbers of COVID-19 cases reported as yet, but this is expected to change over the coming weeks and months especially in poor countries with large cities where social distancing and stay at home strategies are much less able to be managed and the provision of equipment, intensive care, specialist nurses and PPE is significantly limited compared to more wealthy countries. The assumption is that the death rate could be higher, much higher, in these countries ${ }^{12}$. In this context, Latin-America was one of the last territories in the world to be reached by COVID-19. For this region, on April 23, 2020, Brazil is the country with the most confirmed cases $(n=49492)$, followed by Ecuador $(n=22160)$. The government and health authorities of other countries in the region have been making relatively correct decisions for the management of the pandemic. As an example, Colombia decided to carry out social distancing and quarantine measures of the population in an opportune approach. On April 23, 2020, this country reports $n=4561$ confirmed cases of COVID-19 $\frac{13}{}$. However, these data should be taken with caution, given that in the majority of LMICs, governments do not have sufficient resources to realize enough tests to groups of vulnerable population and symptomatic and non-symptomatic patients.

The second is the impact of social distancing and lock down measures on national and global economies and the ramifications for healthcare and society generally from a possible global economic depression ${ }^{14}$. The impact of a great depression maybe more deadly than the COVID-19 virus itself. Many wealthy countries are spending large sums of money trying to maintain their own economies. The concern is that money from wealthy countries that may have gone to aid poorer countries could be withheld or significantly reduced, adding further burden to the communities and people who can least defend themselves against COVID-19.

There is one last shining light of hope that could come from COVID-19, and only time will tell if this occurs. A global pandemic is creating a global response, it has the potential to unite humanity as a cohesive force to help and support each other, to forget about wars, embargoes and other negative traits of international human behaviour and start to see everyone in the world as equals, equally 
susceptible to COVID-19, equally susceptible to a global economic crisis, but equally able to help and support each other to create a better world at the other end of the COVID-19 journey.... We can only hope!

\section{REFERENCES}

1. Fauci AS, Lane HC, Redfield RR. Covid-19 - Navigating the Uncharted. $N$ Engl J Med. 2020;382(13):1268-9. https://doi.org/10.1056/nejme2002387

2. Zhang S, Diao MY, Yu W, Pei L, Lin Z, Chen D. Estimation of the reproductive number of novel coronavirus (COVID-19) and the probable outbreak size on the Diamond Princess cruise ship: A data-driven analysis. Int J Infect Dis. 2020; 93:201-4. https://doi.org/10.1016/j.ijid.2020.02.033

3. Onder G, Rezza G, Brusaferro S. Case-Fatality Rate and Characteristics of Patients Dying in Relation to COVID-19 in Italy. JAMA. 2020. https://doi.org/10.1001/jama.2020.4683

4. WHO. WHO announces COVID-19 outbreak a pandemic. 12 March 2020. Available in: http://www.euro.who.int/en/health-topics/health-emergencies/coronavirus-covid-19/news/ news/2020/3/who-announces-covid-19-outbreak-a-pandemic

5. Cyranoski D. What China's coronavirus response can teach the rest of the world. Nature. 2020; 579(7800):479-80 (2020). https://doi.org/10.1038/d41586-020-00741-X

6. Prime Minister of Australia. Update on coronavirus measures. Media statement. 21 April 2020. Available in: https://www.pm.gov.au/media/update-coronavirus-measures-210420

7. Wade A. Covid 19 coronavirus: Lockdown to lift - Jacinda Ardern says New Zealand to move to level 3 from 11.59pm next Monday. New Zealand Herald. 20 April 2020. Available in:

https://www.nzherald.co.nz/nz/news/article.cfm?c id=1\&objectid=12326157

8. Mitchell G. 'Not enough' intensive care nurses for coronavirus outbreak. Nursing Times. 12 March 2020. Available in: https://www.nursingtimes.net/news/hospital/not-enough-intensive-care-nurses-for-coronavirus-outbreak-12-03-2020/

9. Sandoiu A. Allocating ventilators during COVID-19: What is 'fair'? Medical News Today. 8 April 2020. Available in: https://www.medicalnewstoday.com/articles/allocating-ventilators-duri ng-covid-19-what-is-fair\#The-ventilator-shortage-crisis

10. WHO. Rational use of personal protective equipment for corona virus disease (COVID-19). Interim guidance: 19 March 2020. Available in: https:/apps.who.int/iris/bitstream/handle/10665/331498/WHO-2019-nCoV-IPCPPE_use-2020.2-eng.pdf

11. Williams G, Cañon-Montañez W. International leadership in nursing. Rev Cuid. 2013; 4(1): 433-6. http://dx.doi.org/10.15649/cuidarte.v4i1.1

12. Radbruch L, Knaul FM, de Lima L, de Joncheere C, Bhadelia A. The key role of palliative care in response to the COVID-19 tsunami of suffering. Lancet. 2020. https://doi.org/10.1016/S0140-6736(20)30964-8

13. WHO. Coronavirus disease (COVID-2019) situation reports. 23 April 2020. Available in: https://www.who.int/emergencies/diseases/novel-coronavirus-2019/situation-reports

14. Schwab K, Vanham G. What We Must Do to Prevent a Global COVID-19 Depression. TIME. 9 April 2020. Available in:

https://time.com/5817922/science-collaboration-global-covid-depression/ 